\title{
Comparative preliminary study between the conventional IVF/ICSI and the INVO intra-vaginal device: Stress-related psychological impact
}

\section{Estudo preliminar comparativo entre a FIV/ICSI convencional e o dispositivo intra-vaginal INVO: Impacto psicológico relacionado ao estresse}

\author{
Gabriella Hernandes Vieira e Francisco Augusto Colucci Coelho ${ }^{1}$ \\ ${ }^{1}$ Human Reproduction Service of the Álvaro Alvim School Hospital (Infertility and Fetal Medicine Center in Nor- \\ thern Rio de Janeiro)
}

\section{RESUMO}

Objetivo: Este estudo preliminar do aspecto psicológico buscou conhecer os aspectos emocionais relacionados ao estresse das mulheres que se submeteram ao tratamento de reprodução humana assistida, evidenciando a tecnologia FIV/ICSI e o Dispositivo intravaginal INVO.

Material e Métodos: Foram estudadas 40 mulheres com idade media de 34 anos (29 a 44 anos), tratadas no período de dezembro de 2010 a maio de 2011. As pacientes foram divididas em dois grupos: Grupo 1 (GI) com 20 casais submetidos a FIV/ICSI; Grupo 2 (GII) com 20 casais submetidos ao método INVO. A todas foi aplicado individualmente o ISSL - Inventário de Sintomas de Stress de LIPP, com o objetivo de mensurar níveis de estresse e possibilitar a comparação dos resultados entre as duas técnicas aplicadas. Resultado: Foi observado que embora o estresse esteja presente em todas as mulheres estudadas, o dispositivo INVO comparado ao Método FIV/ICSI levou a melhores resultados no sentido de não desencadear estresse nas pacientes.

Palavras-chave: estresse, infertilidade, FIV/ICSI e dispositivo INVO.

\section{ABSTRACT}

Objective: This preliminary study sought to better understand the psychological aspects related to the emotional stress of women who underwent assisted reproduction treatment, comparing the IVF / ICSI technology and the INVO intra-vaginal device.

Material and Methods: 40 women with an average age of 34 years (29 to 44 years of age) were studied, treated in the period from December 2010 to May 2011. The patients were divided into two groups: Group 1 (GI) with 20 couples undergoing IVF / ICSI, Group 2 (GII) with 20 couples undergoing the INVO method. The ISSL-Inventory of Stress Symptoms of LIPP was individually applied to all the women, with the objective of measuring stress levels and enabling the results comparison between the two techniques applied. Results: It was observed that although stress is present in all women studied, the INVO device compared to the IVF / ICSI method led to better results in the sense of not triggering stress in the female patients.

Key Words: Stress, infertility, IVF / ICSI and INVO device.

\section{INTRODUCTION}

Nowadays, the problematic related to infertility comprises the need of using assisted human reproduction technologies. According to the World Health Organization, approximately 60 to 80 million people in the world, that is, $20 \%$ of all couples in reproductive age experience infertility. A couple is considered infertile when it fails to achieve pregnancy after 12 months of active sexual life and without making use of contraceptive methods (Badalotti \& Petracco, 2007). The chance of a fertile couple achieving pregnancy is of $15 \%$ to $25 \%$ per month (Olmos, 2003). The human fertility is low, in comparison to other species. The result of pregnancy for a normal couple, after intercourse during ovulation period, is estimated in $16.6 \%$ (Passos \& Isabel, 2007).

Someone (man or woman), some relations (between spouses and among the multi-professional staff) and the context in which they are inserted, are all compromised in infertility (Maluf, 2008).

To cover the difficulties related to infertility, science has sought to perform researches and develop technologies on assisted human reproduction (Rowe,et al. 1993), among which there are the artificial insemination, classic in vitro fertilization IVF, intracytoplasmic sperm injection ICSI and INVO. The INVO technique (Ranoux C. \& Frydman, 2008) is a recent technology, developed and improved by the French physician Claude Ranoux, being a result of 30 years of safe and advanced researches, and it has been used by several countries with accentuated approval.

In the conventional IVF or in the ICSI, commonly used procedures, after the egg cells collection, they are placed in plates with the partner's sperm, which had been previously collected and kept in incubators which simulate the conditions in the uterine tubes.

The objective of the INVO technique (Ranoux \& Seibel, 2008 ) is to take advantage of the physiological conditions of temperature and oxygen tension for the development of the pre-embryos provided by means of fertilization and the cultivation of pre-embryos in the vaginal channel. Consequently, there is a bigger participation of the couple in the process, which may repercussions on the resulting stress. Stress (Silva \& Martinez, 2005) can be defined as every reaction of the organism, together with the psychological, physical, mental and hormonal components, which takes place when there is the need of a major adaptation to a stressing event, but which may be harmful in case there is prolonged exposure to the event or a predisposition of the individual to certain illnesses.

This research is set as a preliminary study and the objective of its analysis is to compare the couples' response to stress when undergoing assisted reproductive therapies through INF/ICSI and the INVO technique.

\section{MATERIAL AND METHODS}

40 women with an average age of 34 years ( 29 to 44 years old) were treated in the Human Reproduction Service of the Álvaro Alvim School Hospital / Infertility and Fetal Medicine Center in Northern Rio de Janeiro, in the period from
Recebido em 22-10-2012

Aceito em 03-09-2013
Copyright - Todos os direitos reservados a

SBRA - Sociedade Brasileira de Reprodução Assistida 
December 2010 to May 2011. The exclusion criterion used were the severe male factor and those who did not consent to sign the free and informed consent term.

The female patients were divided into two groups: Group 1 (GI) with 20 couples undergoing the INVO method. Group 2 (GII) with 20 couples undergoing ICSI.

In group I, the classified egg cells were placed for fertilization with the semen which had been capacitated by the swim-up technique, diluted in a concentration of 30,000 to 50,000 spermatozoa per milliliter in SSM (Irvine Scientific $($ ) culture medium with $10 \%$ SSS (Irvine Scientific $($ ), inside the INVOcell ${ }^{\mathrm{TM}}$ device immediately after. After that, The INVOcell ${ }^{\mathrm{TM}}$ device was deposited in the vaginal cavity. The removal of the device took place 72 hours after its collocation. The removed INVOcell ${ }^{\mathrm{TM}}$ was washed with saline at a $37^{\circ} \mathrm{C}$ temperature, and the culture medium contained in the device was analyzed for embryos withdrawal. The embryos produced inside the INVOcell ${ }^{\mathrm{TM}}$ were transferred to well plates and then transferred. The ICSI technique was applied to group II, as universally conducted.

The transfers were performed using a SURE-PRO ULTRA ${ }^{\text {TM }}$ WALLACE $B$ transfer catheter coupled to a 1 milliliter TERUMO ${ }^{\circledR}$ syringe and a disposable speculum. The number of pre-embryos transferred to the uterine cavity followed the Brazilian Resolution from the Federal Medicine Council (CFM 1.957/10).

The evaluation by the psychology sector took place in an initial interview with all the female patients referred by the Biology Sector with psychological anamnesis and an invitation to participation in which the search terms were explained to the female patients with the signing of free and informed consent terms. On the day of aspiration, there was an interview for welcoming and hearing the female patients which accepted taking part in the research, when they had the chance to verbally express the feelings they experienced at the moment of puncture and, on the third post-aspiration day (transfer day), the ISSL - Lipp's Inventory of Stress Symptoms (Lipp, 2000) was applied individually. Lipp (1994) divided the emotional stress into several phases: The positive stress (Lipp, 2000) would be related to the Alert Phase, being the initial phase. The organism produces adrenalin which provides courage, vigor and energy and leads the person to produce more and be more creative, motivated, stronger and more attentive. It is the productivity phase. No one is capable of being alert for a long period of time because the stress becomes excessive when it lasts too long. In this phase, the human being automatically gets prepared for action.

Ideal stress is the one in which the person learns the stress maneuver and manages the alert phase efficiently, shifting between being in alert and not being in alert. The organism needs to enter homeostasis after a period in alert, in orrder to recover. After recovery there is no harm in becoming in alert again. In case there is no recovery period, then diseases start occurring, for the organism exhausts itself and the stress becomes excessive.

Negative stress is the excessive one. It occurs when the person surpasses his/her limits and depletes his/her adaptation capacity. The organism is destitute of nutrients and its mental energy is reduced. Productivity and the capacity to work are rather compromised. Life quality is harmed. And later, the person may fall sick.

The stress may be excessive because the stressor event is far too strong or because it is excessively extended.

The Resistance Phase is when the organism acts to avoid the total energy wastage, accentuating the resistance to the stressors and the organism vulnerability. There is an unconscious attempt to restore the previous balance (called homeostasis) which was broken in the alert phase. Productivity falls dramatically. It is characterized by cortisol production. The person's vulnerability to viruses and bacteria is accentuated.

The Almost-Exhaustion is when the tension exceeds the limits of manageable, both the physical and emotional resistances begin to shatter, there still being moments in which the person can lucidly think, make decisions, laugh of jokes and work, although all these demands efforts and such moments of normal functioning intercalates with moments of total discomfort. There is much anxiety in this phase. The person experiences constant emotional changes. Cortisol is produced in greater quantity and it starts having the negative effect of destroying the immunological defenses. Diseases begin to appear.

The Exhaustion Phase is the most negative stress phase, the pathological one. Is the moment in which there occurs a major interior unbalance, with precipitate decisions, vulnerable to depression and severe diseases such as ulcers, high blood pressure, psoriasis and vitiligo.

The ISSL instrument is formed by three charts referring to the stress phases. The first chart, composed by 15 items, refers to the either physical or psychological symptoms the person experienced in the previous 24 hours. The second chart, composed by 10 physical and 5 psychological symptoms, is related to the symptoms experienced in the previous week, and the third chart, composed by 12 physical and 11 psychological symptoms, refers to the symptoms experienced in the previous month. In total, the ISSL presents 37 items of somatic nature and 19 of psychological nature. The data collected in the application of the ISSL in the GI and GII groups were analyzed and compared, concerning the stress level, and stress phases were verified.

Both the correction and evaluation was initially carried on summing up the symptoms marked in chart 1a (F1) with the ones marked in chart $1 b(P 1)$, then summing up all the symptoms marked in chart $2 a$ (F2) with the ones in chart $2 \mathrm{~b}$ (P2), also summing up the symptoms marked in chart $3 a$ (F3) with the ones in chart 3b (P3), thus obtaining the scores. In the evaluation, in case the gross score from chart 1 was greater than 6 , it indicated the person has stress, and in case it was smaller than that, then it was not considered. In chart 2, if the gross score was greater than 3 it indicated the person has stress, but it was not considered if smaller than that. In chart 3, it was considered to have stress if obtaining a score greater than 8 , but it was not considered if smaller than that. When the limit gross scores were reached, they were considered cases of stress diagnosis. In order to identify the stress phases, the ISSL also indicates, by means of the correction table 1 , checking the 3 percentages obtained, verifying the greatest percentage, which will indicate the stress phase in which the person is. In chart 2 it is possible to verify that it is divided in 2 parts showing the division between the resistance and almost-exhaustion phases, the scores between 4 and 9 indicate the resistance phase, while the scores between 10 and 15 (with percentage above 50 ) indicate the almost-exhaustion phase.

After the transfer the patients were kept under specialized psychological follow-up until the final result.

\section{RESULTS}

The age of the women being studied varied between 29 and 43 years of age (average $=36$ ). The results evidenced that as for the women who utilized the ICSI method $45 \%$ did not present stress (no stress $n=9$ ), $10 \%$ in alert phase $F 1(n=2), 20 \%$ in resistance phase F2 $(n=4), 25 \%$ in exhaustion phase $F 3(n=3)$. And as for the women who utilized the INVO technology: $60 \%$ no stress $(n=12), 15 \%$

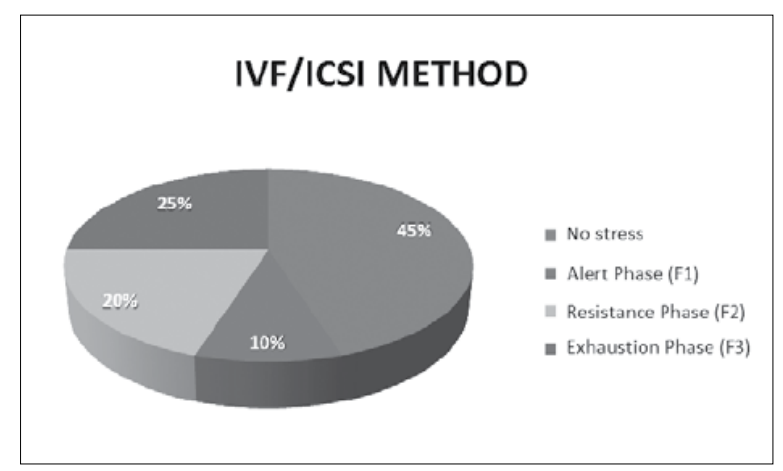




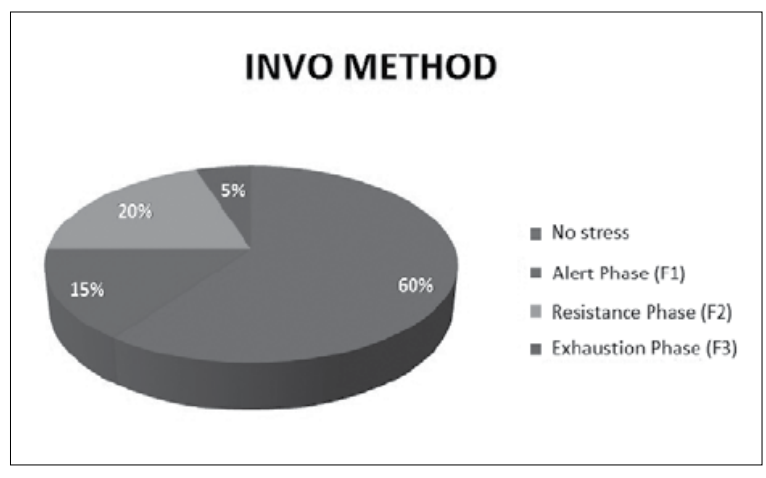

alert phase $F 1(n=3), 20 \%$ resistance phase $(n=4)$, and $5 \%$ exhaustion phase $(n=1)$.

It can be observed that stress is present in the couples which undergo infertility treatments. However, comparing the women who experienced the ART treatment with INVO and IVF, it can be understood that a significant quantity of women $(60 \%)$ who experienced treatment with the INVO technology did not present stress in this study. Besides, those who did present stress, $15 \%$ were in the alert phase (which is considered the positive stress phase), while as for the ones who utilized the IVF, $10 \%$ were in the alert phase. Regarding the resistance phase the results did not present significant difference. There was no case of almost-exhaustion phase either. And concerning the exhaustion phase (which is considered the most negative and pathologic phase) the IVF obtained $25 \%$, and the INVO method only $5 \%$.

\section{DISCUSSION}

The INVOcell device (Ranoux \& Seibel, 1990) comprehends a small capsule which is used in the treatment of infertility, with the objective of incubating egg cells and spermatozoa for the development of pre-embryos.

It is a technology which enables the cultivation of gametes in a physiological environment for the cultivation of oocytes, and alternative for couples with history of fertilization difficulties (Volgsten, et al. 2008). It consists of the fertilization of the oocytes by means of the INVOcell ${ }^{\mathrm{TM}}$ device composed of material permeable to gases, taking advantage of the temperature and oxygen tension conditions of the vaginal epithelium. It is considered a fertilization technique (more simplified) of embryos. The principle is simple and the future mother's vagina plays the role of incubator. The device isolates the gametes from the vaginal environment, but it allows the gases exchanges and it benefits from the body temperature reproducing the body physiology conditions.

To perform this (INVO) treatment, few medical consultations would be needed, which was considered as beneficial by the women participating in this research. They said it causes less pressure and give them more confidence, because they knew they would be participating in a most natural protocol as possible.

The INVO and the IVF/ICSI vary in their technology aspects and there may be differences in the emotional aspects (Bury, 1982), maybe varying regarding the women's stress during treatment, as the data from this preliminary study indicate.

The INVO offers the patients a more personal approach to achieve pregnancy, an involvement which the patients seek when undergoing treatment (Carvalho, et al,2006), providing a less cold treatment, more humanized.

In the initial interviews the patients reported more confidence, being closer to the treatment they felt participants in the process, as the capsules with the gametes were with them, they reported it was affectively important to be near the gametes, "they come home with me, not being left in the lab", one of the patients reported.
With the INVO process the extent of work of advanced technologies in assisted human reproduction is increased, providing a greater number of patients with the opportunity of receiving the infertility treatment, as well as increasing the opportunity of access to all strata in society, for it is financially more accessible.

Besides, the cultural aspects and religious beliefs interfere in the choice of the treatment by the couple in many cases (Borlot \& Trindade, 2011), in the case of INVO, such difficulties related to religion do not configure as a problematic, as the fecundation does not occur outside the mother's body, being considered by many authors an aspect that still promotes the woman's well being.

Therefore, with the INVO many couples which present feelings of guilt related to the religious criteria and society demands will be capable of feeling more assertive.

Concerning stress (Sarda, et al. 2004), in this research stress was considered a non-specific reaction of the organism in face of a situation interpreted as threatening. What triggers such response is the organism evaluation of the situation.

The analysis, as for the stress level, followed the measurements established by the ISSL (Lipp, 2000). They evidenced that even though stress is present in the women who experienced infertility treatment, the INVO method, as the stressor and compared to the IVF/ICSI method, may be indicated as it obtained better results in the sense of not triggering stress, and as for the phases in which the patients which presented stress were the conventional IVF/ICSI method obtained higher results in the negative stress, which in excess is harmful and depletes de capacity of adaptation. In the group which underwent the INVO method there were transfers in 18 cycles and 6 patients tested positive and pregnancy. Among those, one case evolved into abortion in week 7.

\section{CONCLUSION}

This preliminary study reveals the importance of psychology in the approach regarding patients' stress in infertility treatment, because stress is present in all patients being treated. Nevertheless, the INVO, compared to ICSI, provides a greater participation of women in the treatment, requiring fewer visits to the service, with medication protocol (minimum stimulus) occurring reduction in pain, anxiety and even hormonal effects from medication. It assures a greater adhesion to the treatment, and increase in the index of the patient's return to the treatment in negative cases in the first attempt and better results as for not triggering negative stress.

\section{Corresponding Author}

Gabriella Hernandes Vieira

Centro de Infertilidade e Medicina Fetal no Norte Fluminense

Rua Barão da Lagoa Dourada, 409 - 20. Andar / Hospital Escola Álvaro Alvim

CEP: 28035211 - Campos dos Goytacazes - RJ - Brasil

Telephone Numbers: (+5522) 2723-1277 / 2734-

9078/ 9941-1042/ 8148-4153

E-mail: gabriella@centrodeinfertilidade.com.br / gabihvieira@hotmail.com

\section{REFERENCES}

BADALOTTI M \& PETRACCO A. Infertilidade: definições e epidemiologia in M. Badalotti, A. Petracco \& Teloken (tds:), Fertilidade e infertilidade humana 2007: 3-7.

BORLOT AMM. TRINDADE, ZA. As tecnologias de reprodução assistida e as representações sociais de filho biológico. Estud. psicol. (Natal), abr 2004; 9 (1):63-70 (20/05/2011).

BURY M, (1982). Choric Illness as a biographic discuption in E. Hardy. Reprodução assistida: conseqüências psicológicas e sociais. Anais do $18^{\circ}$. Congresso Brasileiro de Reprodução Humana, 7-10 de novembro de 1998, Porto Alegre. 
CARVALHO CAP, SEIBEL D, MAKUCH MY, MALUF VD.Guia sobre saúde mental e reprodução humana. Comitê de Psicologia da SBRH 2006;52.

KLERK C, PASSCHIER J, MACKLON NS \& ERASMUS MC. The effect of pre-treatment and procedural stress during a first IVF cycle on live birth delivery. Available in internet <http://www. eshre.com/emc.asp?pageId=302> $(20 / 05 / 2011)$

LIPP, M.E.N. Inventário de sintomas do stress para adultos. São Paulo: Casa do Psicólogo, 2000.

LIPP, M.E.N. \& Guevara, A.J.H. (1994). Validação empírica do inventário de sintomas de estresse. Estudos de psicologia, 11(3), 43-49.

MALUF, V. Fertilidade \& maternidade: o desejo de um filho- São Paulo: Atheneu, 2008.

OLMOS EP. Quando a cegonha não vem. São Paulo: Carrenho editorial; 2003

PASSOS, E. P. A.; ISABEL, F. P. Quando a gravidez não acontece. Porto Alegre: Artmed, 2007
RANOUX C. e SEIBEL M. Renew- new techniques in fertilization: intravaginal culture and microvolume straw. Journal of in vitro fertilization and embryo transfer. 1990.

RANOUX C. FRYDMAN R. Invo: a simple, low cost effective assisted reproductive technology. Human Reprodution, 2008.

ROWE PJ, COMHAIRE FH, HARGREAVE TB \& MELLOWS HJ, Manual for standardized investigation and diagnosis of infertility couple. Cambridge (UK): 1993.

SARDA,J.Jr, LGELA,E.J.J.Jr, SERGIO, J. Estresse: conceitos, métodos, medidas e possibilidades de intervenção. São Paulo: Casa do Psicólogo, 2004.

SILVA, E. A. T. da; MARTINEZ, A. Diferença em nível de stress em duas amostras: capital e interior do estado de São Paulo. Estud. psicol. (Campinas), Campinas, v. 22, n. 1, mar. 2005. (28/05/2011)

VOLGSTEN $H$, SVANBER AS, EKSELIUS L, LUNDKVIST Ö, POROMAA IS, Prevalence of psiquiatric disorder in infertile women and men undergoing in vitro fertilizayion treatment. Human Reproduction. 2008; 23 (9): 2056- 2063. 